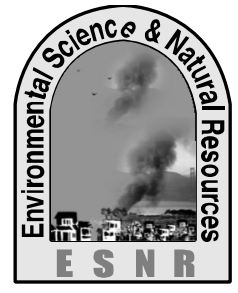

\title{
Studies on the Culture Condition of Pangus (Pangasius hypophthalmus) at Different Farms in Trishal Upazila
}

\section{I. Hossain, F. H. Shikha* and T. Chakrabarty}

\author{
Department of Fisheries Technology, Bangladesh Agricultural University, Mymensingh-2202, \\ Bangladesh \\ *Corresponding author: shikhafh@ bau.edu.bd
}

\begin{abstract}
The present study was conducted to investigate existing culture conditions of pangus (Pangasius hypophthalmus) at farms in Trishal Upazila under Mymensingh district during January to June, 2016. Data were collected with questionnaire by personal interviewing of the respondents. The study result showed that- the farmers of large category are about $60 \%$ where $47 \%$ farmers have leased pond. Most of the farmer use deep tube-well water as source, $87 \%$ farmers practice monoculture of pangus and monitored the health of fish in a regular basis. Only 13\% farmer reported diseases occurred in their pond. Most of the pangus farmers used homemade or local farm made supplementary feeds for pangus culture. The study showed that development of better farming system, improving water management, stocking of quality fingerlings, health monitoring and use of prime and standard quality feed has resulted better pangus production in Trishal area.
\end{abstract}

Key words: Better production, Culture condition, Farms, Pangus (Pangasius hypophthalmus), Trishal Upazila

\section{Introduction}

Among the various culture species of catfish, Pangasius hypophthalmus is particularly important. Pangasius hypophthalmus was introduced in Bangladesh from Thailand in 1989. Later, induced breeding of this species was first accomplished successfully in 1991 at BAU and BFRI. Then the artificial propagation practiced over the country and it gained much popularity in Bangladesh because of its rapid growth, ease culture technique, high disease resistant and tolerance to a wide range of environmental adaptation (Bardach et al., 1972). $P$. hypophthalmus is well accepted by a wide range of people and therefore, it has been a good source of protein and calorie for poor, medium and better-off people in rural as well as urban areas. People of this country were economically benefited from this industry. It has gained a momentum in Bogra, Jessore, Noakhali, and Dhaka and mainly in Mymensingh district for high growth, high demand and high market price.

Pangus farming was first started by private enterprise in Trishal. The number of pangus farms is higher in Dhanikhola compared to other areas of Trishal upazila (Ali, 2010). This village was a typical pangus producing area in terms of early development, having large number of farms, higher production level and better access to the markets. Over the years pangus production has increased due to its year round breeding and spawning response for fry production, nursing of fingerlings and trading, fish culture and fish trading which ultimately proved itself as a profitable aquaculture enterprise (Monir, 2009). Production of cultured fish can be increased by making best utilization of the existing inland resources through modern and scientific methods of fish culture and fishing techniques. Similarly, successful and sustainable fish culture also depends on an effective marketing and distribution system (Alam et al., 2012).

Polyculture of Pangus ( $P$. hypophthalmus) with carps is the existing culture practice along with monoculture being practiced by many households in Bangladesh. Recent survey shows that- in most of ponds of Bangladesh fish are not cultured in planned and scientific way, which hampers the pond fish farmers to improve their production and socio-economic status (Ali and Rahman, 1986). Over the last two decades though a spectacular development has taken place in farming of pangus in Bangladesh but in the recent years, economic benefit from this farming is being depleted partly due to increasing feed cost, lack of proper management, unavailability of low cost supplementary feeds and some socio-economic constraints (Akter, 2001). As a result, it was reported that pangus farmers are gradually losing their interest to invest in pangus farming in the study area (Wahab et al. 2008).

To fulfill the need of time, dependency on culture fisheries and pond aquaculture, improvement of cultural system and future planning, the information regarding present status of pangus culture practices at the grass root 
level is necessary. In fact, very little economic investigations for fish farming have so far been undertaken by the researchers in Bangladesh. Therefore, the present study has been undertaken to study the culture condition (culture technique, production, economic issues, constraints, etc.) of pangus at farms of Trishal Upazila.

\section{Selection of the study area}

Materials and Methods

Selection of an area is an important task for fulfilling the objectives and setting the study. This study was conducted in three unions of Trishal upazila named
Mathbari, Dhanikhola and Trishal Sodor under Mymensingh district (Fig. 1). These three unions were selected for this study considering the reasons i) Pangus farming first started by private enterprise in Trishal which was very close of the study area, ii) Dhanikhola was a typical pangus producing area in terms of early development, iii) Having large number of farms, higher production level and better access to the markets, iv) Commercial pangus farming is usually done in this area, v) Well communication facilities from and to all over Bangladesh (good communication facilities from the Bangladesh Agricultural University (BAU) to the study) vi) Expectation of getting cooperation from fish farmers.

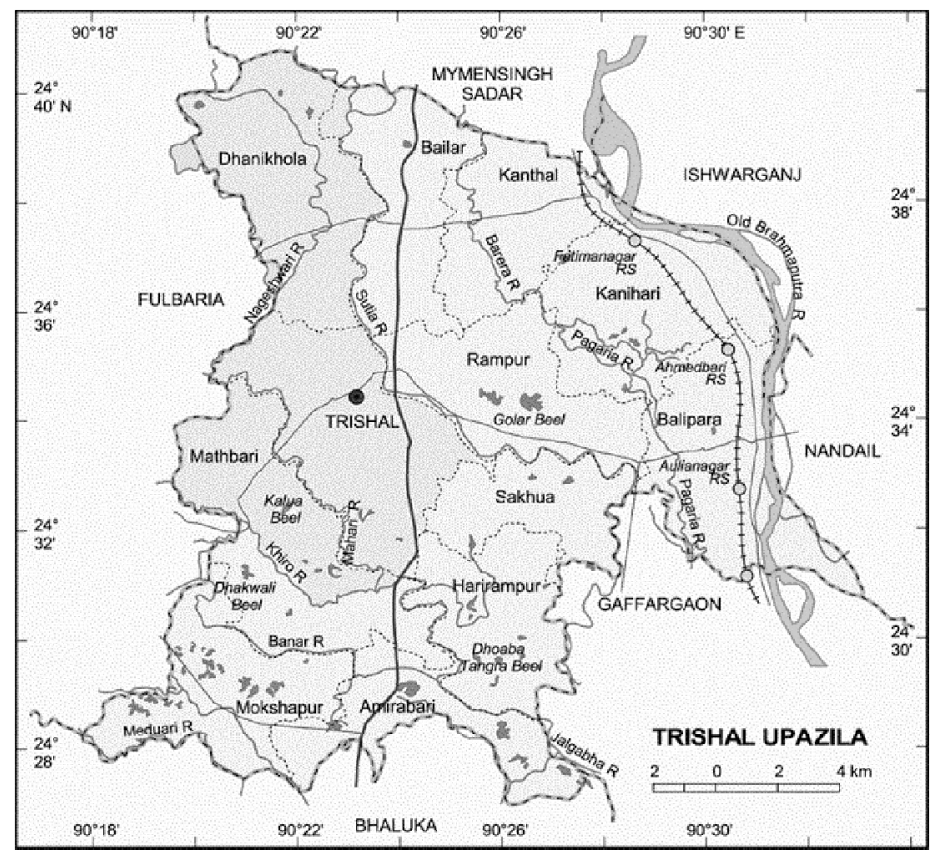

Fig. 1. Map of Trishal Upazila (the study area)

\section{Period of the study}

During study, the data were collected intensively by using structured survey schedules in recall method. The collection of data covered a period of six months from January to June, 2016.

\section{Sampling of farm}

The study was conducted on a total of 15 pangus aquaculture farms of Mathbari, Dhanikhola and Sakhua village in Trishal upazila under Mymensingh district. The sampling was done in random manners.

\section{Preparation of questionnaire}

In order to get a complete picture of pangas farming to fulfill the objectives of the study, a questionnaire was prepared. The draft questionnaire was used for pre- testing with a few sample respondents by the information designed to include farming. The questions of the questionnaire were basically structured with some openended questions. All the questionnaires were constructed in English and then translated to Bengali during face-toface interview.

\section{Data collection method}

In order to collect data primarily, individual interview technique was followed i.e. data were collected directly from the selected farmers who were engaged in pangus aquaculture. After completing primary data collection procedure, focus group discussion with farmers and cross-check interviews with key informants were carried out to justify the previously collected data. 

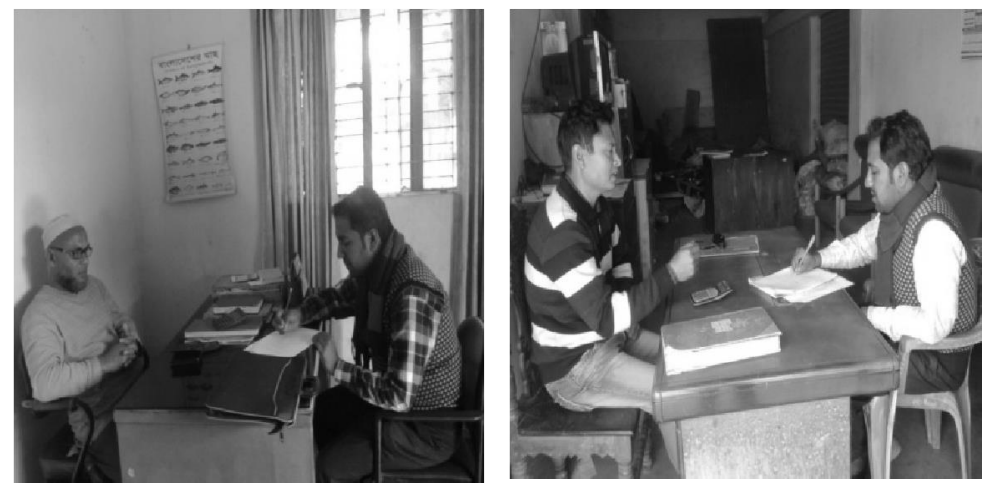

Plate 1. Data collection from farmers

\section{Questionnaire interview}

The data were collected through direct interviews with people involved in pangus farming activities. The interviews were conducted early in the morning because at that time respondents were in house or in the working place. Before interview each respondent was given a brief introduction about the nature and purpose of the study. Then the questions were asked in turn with replies being recorded directly on the questionnaire. When each interview was over, each questionnaire was checked and verified to be sure that answer to each item was required about an hour. If there were any items, which were overlooked or contradictory, the respondents were revised to obtain the missing and /or correct information.

\section{Data analysis}

After collecting various data, statistical analysis was done to know the variance between different answers and the significant level of those results. Data were processed using Microsoft excel. Data are represented within the view of pie diagram, table form and bar diagram.

\section{Results and Discussion}

\section{Information on Pangus Farming}

\section{Establishment of Pangas Farming}

During the survey, it has been known that the culture of pangus started at Trishal upazila of Mymensingh region by some rich people (mainly construction contractors) in leased ponds. Observing fast growth, high yield and net profit many local farmers and young educated people became motivated and started pangus farming. In this way pangus farming expanded in the region within a few years. Presently pangus are cultured in almost all Upazilas of the Mymensingh district and relatively at higher level in Trishal Upazila. Among the sampled farmers of Trishal, 6\% pangus farmers started pangus farming in 1991-95, 22\% farmers started in 1996-2000. $38 \%$ started in $2001-05,22 \%$ farmers started in 2006-10 and another 12\% farmers started in 2011-2015 (Fig. 2). However, the trend of pangus farming is still increasing in this area. Sadi (2013) reported that 7\% farmers started pangus farming in $2010-11,33 \%$ in $2005-06,44 \%$ in 2000-2001 and 16\% farmers in 1995-96 in Muktagacha, Valuka and Trishal Upazilla.

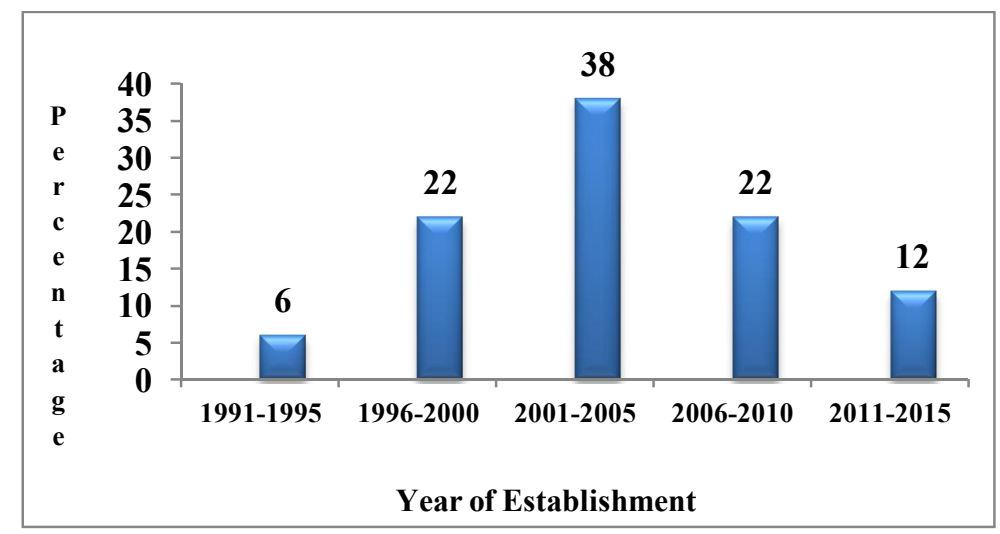

Fig. 2. Year wise establishment of pangus farms 
Category of pangus farmers on the basis of farm size Among the pangus farmers in studied area, 60\% was found to be small ( $<10$ acre), $27 \%$ medium (10-50 acre) and $13 \%$ large (>50 acre) farmers. The number of small and medium farmerôs found higher in number at selected study area (Fig. 3).

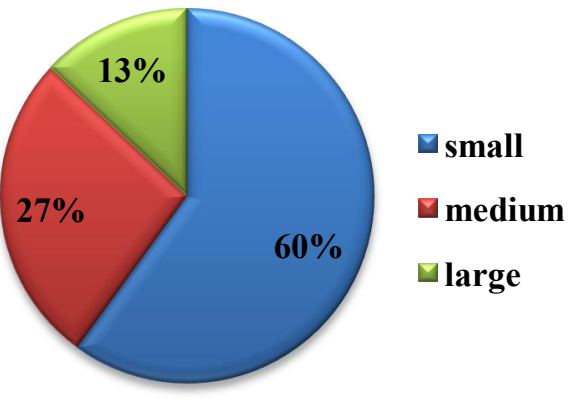

Farmers Category

Fig. 3. Category of pangus farmers on the basis of farm size

\section{Training status of fish farmers}

It was found that most of the farmers learn the fish culture technology themselves through learning by doing, that is culture in successive years and sharing of knowledge among the fellow farmers. About $67 \%$ farmer received training from various NGOôs and GOôs on fish culture and 33\% not received any kind of training (Fig.
4). Rahman (2003) found in his study in Gazipur district that about $49 \%$ farmers gained fish farming experience from friends and neighbors. Saha (2006) observed in his study that about $45.6 \%$ pangus farmers gained experience from friends and neighbors and nobody received formal training. Rahman (2003) reported that about $49 \%$ farmers received formal training.

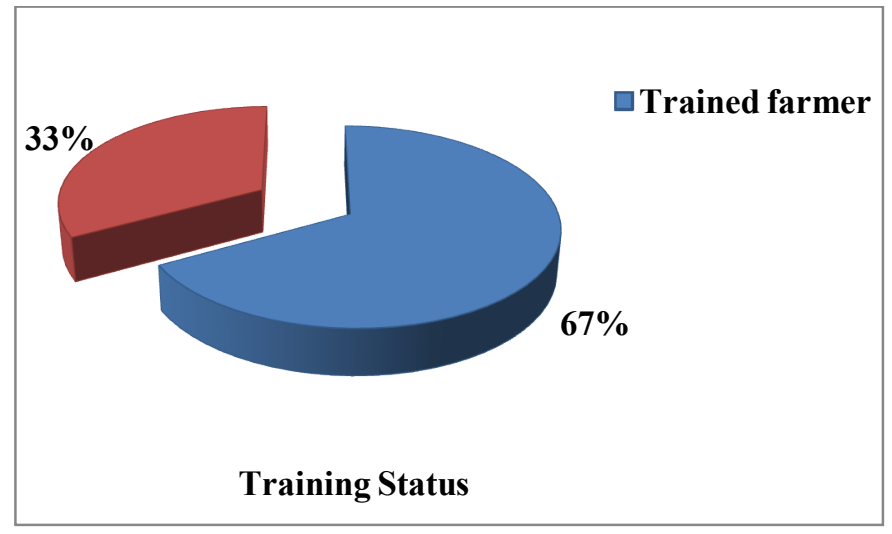

Fig. 4. Training status of fish farming

\section{Ownership of the ponds}

In the study area, $40 \%$ of the farmers have their own pond without partnership $13 \%$ have leased ponds and rest $47 \%$ have both leased and own ponds (Fig. 5). Quddus et al., (2000) observed that $34 \%$ of the ponds were leased ponds another rest $12 \%$ ponds were public or organizational property in Demra, Dhaka. In the study area, lease value of land is BDT 35,000-45,000 /ha/yr which varies with the pond location, pond productivity and pond size. Kundu (2006) found that the leasing cost at BDT 25,000-35,000/ha/yr for fish farming in Khulna district. 


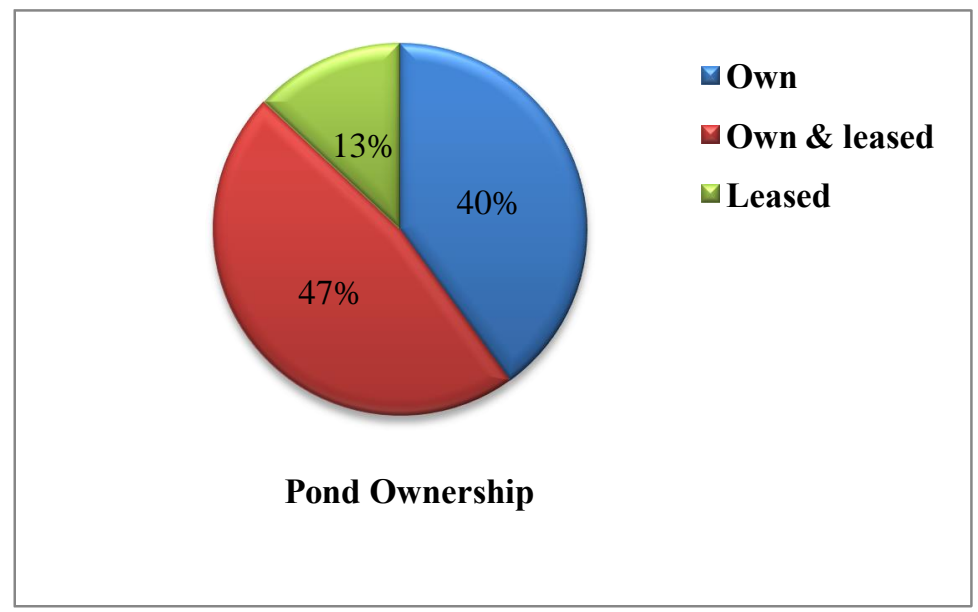

Fig. 5. Distribution of pond ownership

\section{Sources of pond water}

Success of traditional aquaculture depends on the supply of sufficient amount of good quality water. Supply of water in the pond can be from two main sources- rain water and ground water. Distribution of the sources of pond water is shown in Fig. 6. It was found that $13 \%$ ponds depend on river water, $67 \%$ ponds depend on ground water supply using deep tube-well and 20\% ponds depend on both ground water and river in the study area. They usually add water when needed. Temperature created various problems such as oxygen depletion; water quality deterioration etc. and excess rainfall flooded the ponds in summer month.

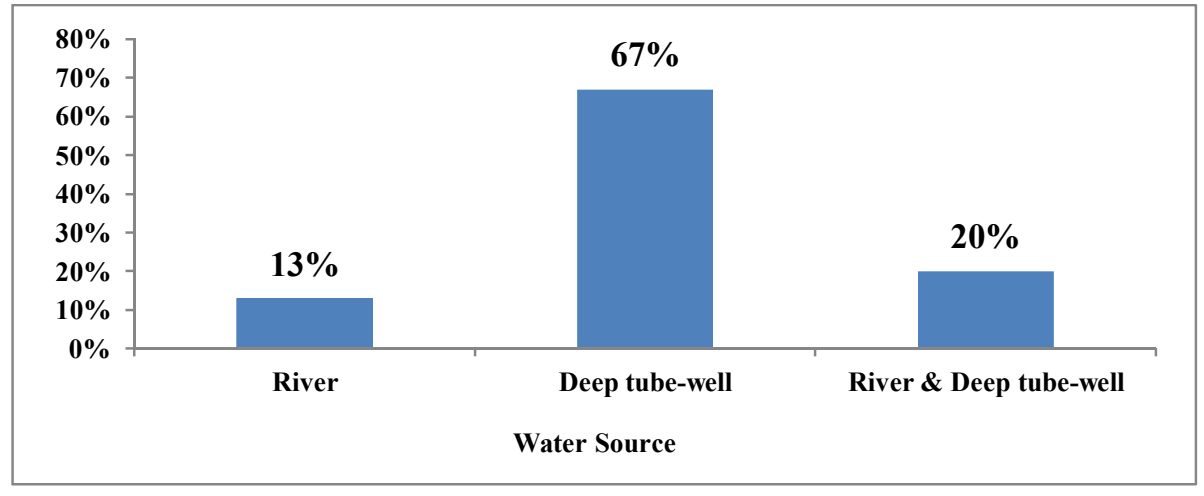

Fig. 6. Sources of pond water

\section{Soil types of pond}

Loamy soil is suitable for aquaculture farming. From the study area, it was found that $67 \% \%$ of pond had loamy soil $20 \%$ had sandy and $13 \%$ had silt loamy soil (Fig. 7). In loamy soil area, ponds have high capacity of water holding with less turbidity problem and high productivity that is potential for other land based aquaculture systems. On the contrary, Ali and Rahman (1986) stated that sandy soil of the ponds was a major problem with $19 \%$ of the fish pond owners in Rangpur district.

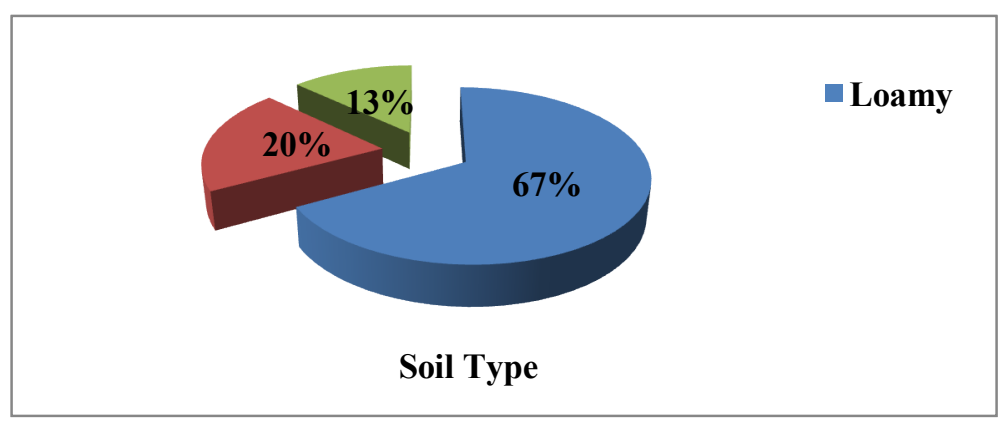

Fig. 7. Soil types of fish pond in the study area 


\section{Culture season and methods}

In the study area, the best season of fish farming was reported to be started in January and end in May. The fish fingerlings are stocked in May to June and harvested from November to January. It was also found that $87 \%$ farmers cultured pangus with other fish (polyculture), whereas $13 \%$ farmers cultured only pangus (monoculture). The highest percentage of polyculture farmers was found in this area (Fig. 8). Maximum polyculture farmers used carps including Rohu (Labeo rohita), Silver carp (Hypophthalmichthys molitrix), Catla
(Catla catla), Mrigal (Cirrhinus cirrhosus), Tilapia (Tilapia mossambica) and Nilotica (Tilapia nilotica) with Pangasius (Pangasius hypophthalmus). Ahmed (2003) observed the best period of polyculture was from April to December. Hossain (2001) reported only 26\% of the ponds were used for culture of monoculture and $74 \%$ of the ponds were used for Pangasius with Indian major carps. From the survey, it was found that $92 \%$ farmers carried out polyculture system. Rahman (2006) showed that around $90 \%$ of the farmers cultured pangasius with carps.

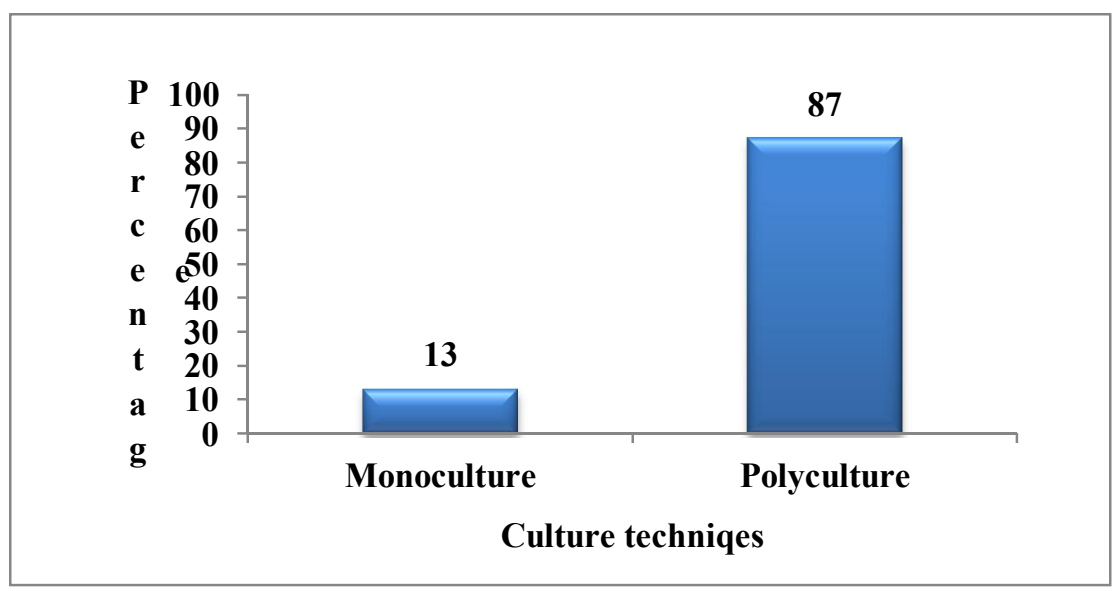

Fig. 8. Fish culture techniques in terms of species composition in the study area

\section{Pre-stocking pond management}

Pond preparation before stocking of fish fingerlings is an important part of pond management. Most of the surveyed farmers made necessary preparation before stocking of fingerlings. The unwanted fish, mainly small indigenous fish species were removed from most of the surveyed ponds. In the study area about $60 \%$ farmer control weed, $73 \%$ farmer dry their ponds, $80 \%$ farmer repair the pond dykes and $67 \%$ farmer remove the bottom mud (Fig. 9). Dyke is the most important part of fish farm. It provides the physical structure of the ponds and obstructs the fish to escape from the ponds. The dyke should be wide enough to allow the worker to walk around the ponds in carrying feeds, monitoring and harvesting (New and Singholka, 1985). In the present study, it was found that $15 \%$ farmers repaired pond dykes.

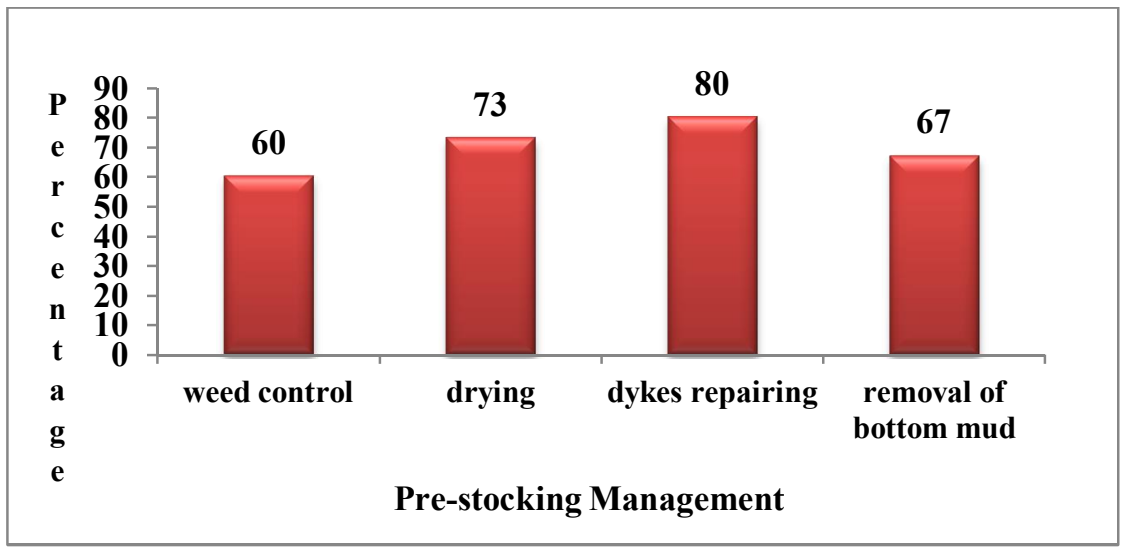

Fig. 9. Pre-stocking management in the study area 


\section{Drainage facilities}

Drainage system is important for entering of new water and exit of waste water. In the study area about $60 \%$ farms have drainage system. But those farms which have no drainage system are thinking about this facility to keep their pond environment clean and healthy.

\section{Source of fish fingerlings}

Traders were the main sources of supplying fish fries/fingerlings to the farmers. About $60 \%$ of the farmers collected fries/fingerlings from the fry traders, $7 \%$ from the government farms, $13 \%$ from the local private farms or nurseries, $7 \%$ from own nursery and other $7 \%$ from both fry trader and local hatcheries. The traders brought fish fries and fingerlings in the study areas from private nurseries in Bogra, some of them were collected from BFRI and other local hatcheries (Fig. 10).

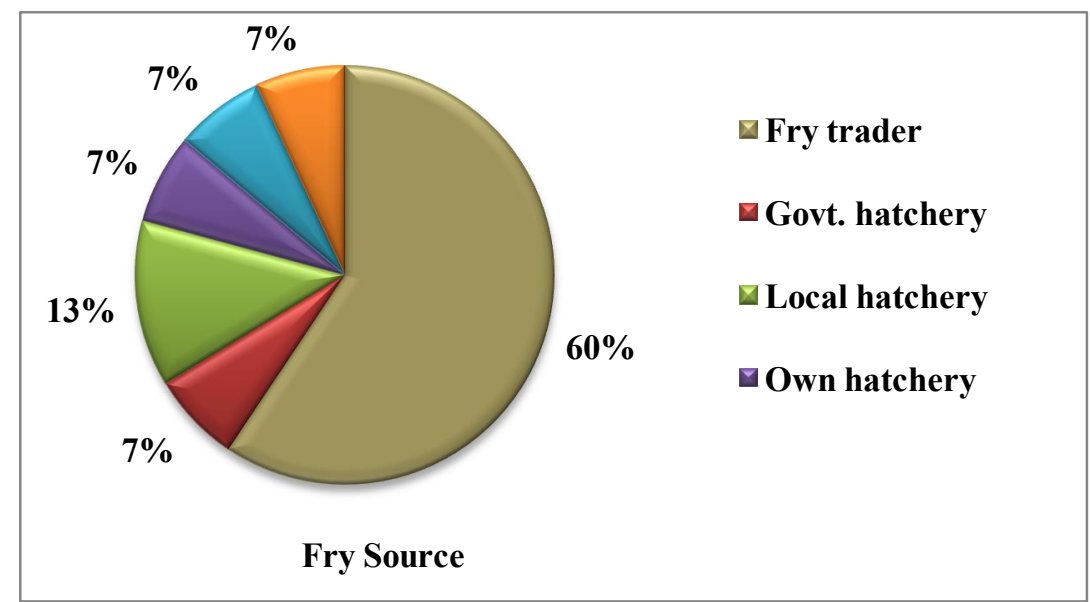

Fig. 10. Sources of fingerlings in the study area

\section{Stocking density/decimal}

Fingerlings size varies from 1-2 inch with price of BDT 2-3/fingerling. The traders transported fish fingerlings in PVC drums on pickup vans. The quality fish fingerlings have a major impact on production and profitability in fish farming. Therefore, the farmers were reported to be always eager to select good quality fingerlings to ensure profitable harvest. Farmers complained about the low quality fingerlings for inbreeding problem that supplied by the traders. In the study areas $90 \%$ of the pangus farmers whether large, medium or small stocked pangus fingerlings in twice a year, for the first crop during February to March and for the second crop during June to
July. In a pond about $72 \%$ Pangus fingerlings are stocked with more or less $28 \%$ carps and other species (Fig. 11). Hossain (2006) found that average stocking density was 24,206 fry/ha. Hasanuzzaman (1997) observed the average stocking density of $16,196 \mathrm{fry} / \mathrm{ha}$ in the district of Rajshahi. Hossain et. al. (1992) found the range of stoking density from 10,000 to 31,000 fry/ha. Akter (2001) found that the average stocking density was 26,309 fry/ha. Kausari (2001) found average stocking density 30,875 fry/ha in a village of Mymensingh district. However in the present study, farmers followed higher level of stocking compared to available literature suggesting fish farming getting intensified gradually.

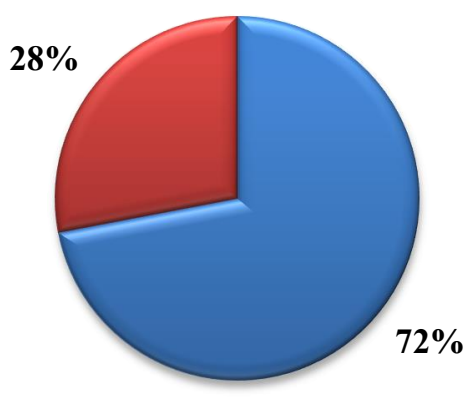

$\square$ Pangus

口Others

\section{Stocking Density/Decimal}

Fig. 11. Stocking density of pangus with other species 


\section{Feeding and feed management for fish farming}

Supply of supplementary feeds, which can complement nutritional deficiency, is important to increase fish production. It does vary according to intensity of cultivation. In the study area, it was observed that the pond fish farmers used wheat bran, rice bran, bone meal, meat \& meal, soybean meal, mustard oilcake, rice polish, corn, salt, vitamin premix and molasses in their fish ponds (Fig. 12). About 60\% farmers had their own mills for producing feeds (Fig. 12). In the study areas fish were fed at high rates. Parvin (2011) found $90 \%$ farmers used commercial pelleted feeds and $10 \%$ farmers used farm made feed for rearing fishes in Mymensingh district.
Akter (2001) observed that the total rate of feed used was $6,751 \mathrm{~kg} / \mathrm{ha}$ which were separately given as rice polish $(1,598 \mathrm{~kg})$, wheat bran $(870 \mathrm{~kg})$, oilcake $(2,540 \mathrm{~kg})$, vitamin $(41 \mathrm{~kg})$ and fish meal $(1,702 \mathrm{~kg})$. Some farmers were found to adjust the feed quality based on visual observation of fish growth and some others by measuring the weight of a small number of stocked fishes. Most of the farmers fed their fishes normally two times a day and the others three times a day. In the study area, food conversion ratio (FCR) was 2 . The average quantity feed used by the farmers in the study area was found to be $55,000 / \mathrm{kg} / \mathrm{ha} / \mathrm{yr}$.

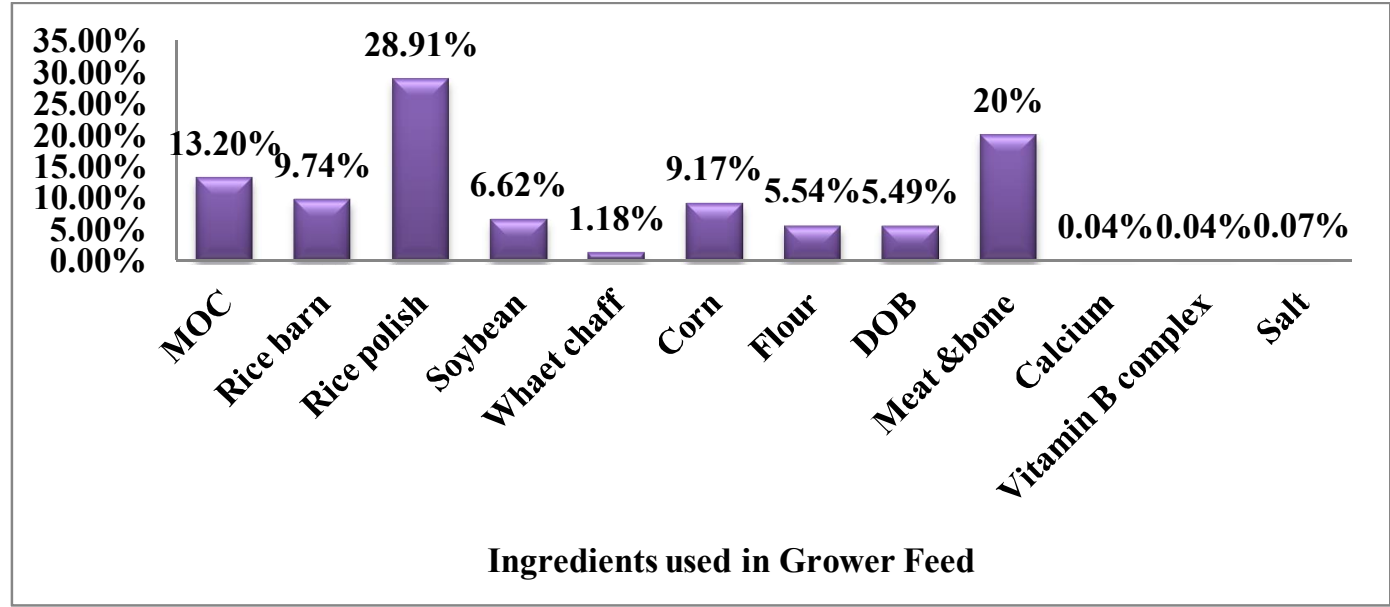

Fig. 12. Ingredients used in grower feed made in local and own mill

\section{Disease occurrence in fish ponds}

It was found from the study area that $60 \%$ fish farms were affected by disease in past. But now a day only $13 \%$ farms report symptoms of diseases and $87 \%$ farms have no disease in their farm throughout the farming cycle (Fig. 13). Major diseases or clinical signs including ulcer, tail and fin rot, gill rot, pop eye and black spot in skin etc were found in the study area (Table 1).

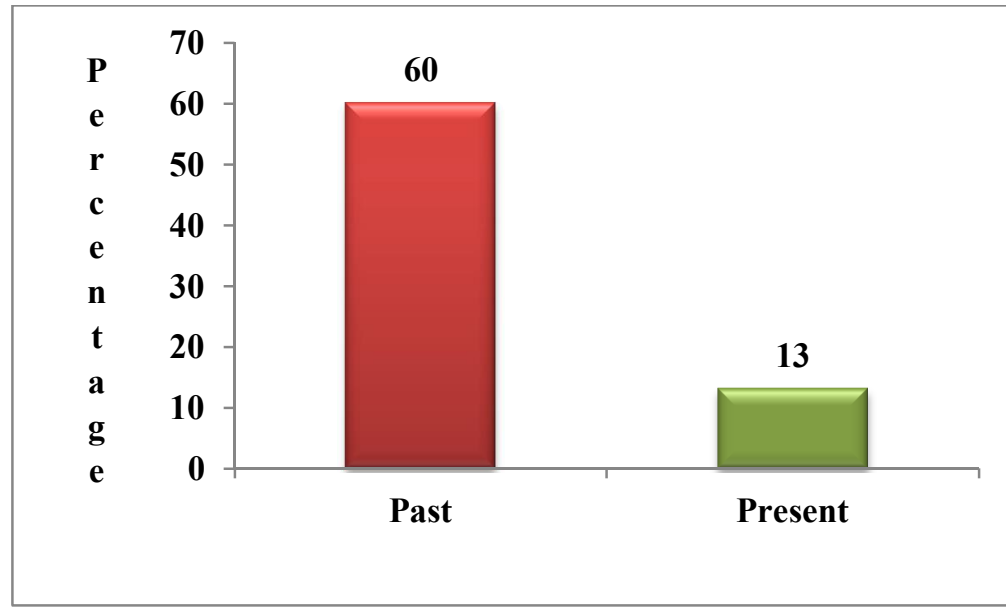

Fig. 13. Disease occurrence 
Table 1. Major symptoms found in pangus Farm in Trishal

\begin{tabular}{|l|c|c|c|c|c|c|c|c|c|}
\hline Symptoms & Fin Rot & Ulcer & $\begin{array}{c}\text { Loss of } \\
\text { Appetite }\end{array}$ & Argulas & $\begin{array}{l}\text { Pale } \\
\text { Body }\end{array}$ & Gill Rot & $\begin{array}{c}\text { Floating } \\
\text { on } \\
\text { Surface }\end{array}$ & $\begin{array}{c}\text { Pop } \\
\text { Eye }\end{array}$ & Death \\
\hline $\begin{array}{l}\text { (\%) Farmer } \\
\text { report }\end{array}$ & 40 & 87 & 13 & 20 & 7 & 13 & 20 & 13 & 40 \\
\hline
\end{tabular}

\section{Health monitoring and chemical treatment}

In the study area the fish health monitored periodically at different interval (Fig. 14). If any kinds of symptom found then farmer use about $620 \mathrm{~g}$ salt, $365 \mathrm{~g}$ lime, $15 \mathrm{~g}$ potash and more or less 100g other drugs such as Aqua-z, Aqua-clean, Tetracycline, zeolite, timsen, Renamycine etc. About $87 \%$ farmer use salt, $80 \%$ use lime, $53 \%$ use potash and $60 \%$ use various drugs (Fig. 15).

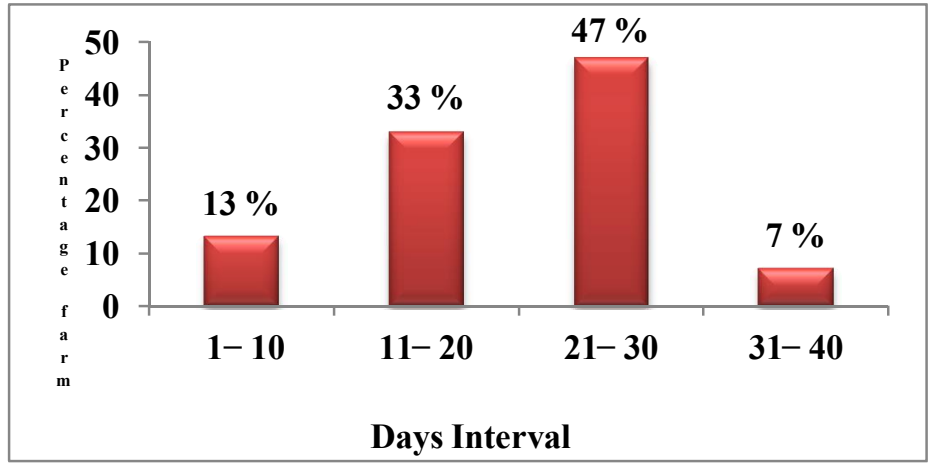

Fig. 14. Health monitoring in the study area

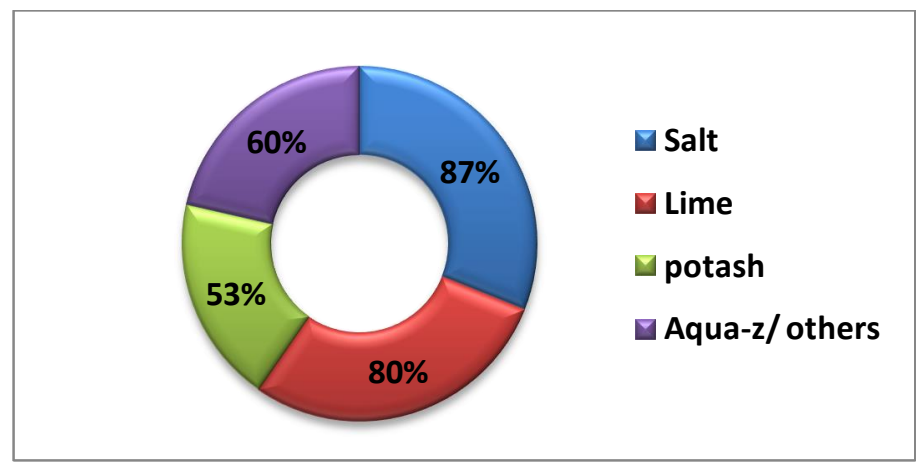

Fig. 15. Chemical treatment in the study area

\section{Pangus productivity and marketing}

Fish production

In the study area, it was found that $87 \%$ ponds were under polyculture system and farmers stocked mainly pangus along with Indian major carps. According to the 15 fish farmers, average production of pangus was $40,765 \mathrm{~kg} / \mathrm{ha} / \mathrm{yr}$ and for carps $1200 \mathrm{~kg} / \mathrm{ha} / \mathrm{yr}$. Rahman et. al (1992) obtained $41.36 \mathrm{~kg} /$ decimal (9.97 t/ha) fish in a polyculture experiment with pangus and carps. Akter (2001) conducted a survey in Trishal upazila under Mymensingh district and found that average production of was $20,112 \mathrm{~kg} / \mathrm{ha}$.

\section{Harvesting and marketing of fish}

In the study area, the best harvesting season were found to be June to July and November to January. It was also found that $90 \%$ farmers harvested their fish completely and only $10 \%$ of farmers harvested partially. The farmers were reported to harvest their farmed fish when it reached around $500 \mathrm{~g}$ to $1 \mathrm{~kg}$ in size. Normally all the fishes of a crop in a pond were harvested at a time and then the ponds were made ready for the second crop of the year. Those who cultured only one crop in a year harvested fish when it reached about 1 to $1.5 \mathrm{~kg}$ in size in $10-11$ months. Some large farmers reported to have their own fishing net and fisher group formed by the farm labors. In the community there are separate fishers group with nets 
formed by rural poor who do fishing farmers pond on contract basis. In the study area, 94\% of the farmers reported to sell their fishes mostly to small traders and occasionally to larger traders. The small traders sell the fishes to retailers in local markets and in neighboring districts, sometimes to larges traders. The medium and large farmers (90\%) sell their fishes to large traders who transport the fish in live condition to Dhaka, the capital city and the northern districts of the country. The fish are transported in PVC drums with freshwater. The selling price of fish varied according to the size and qualities; however the average selling price of pangus was BDT $80-85$ per $\mathrm{kg}$ and exotic carps was BDT 120-130 per kg.

\section{Constraints in pangus farming}

The pangus farmers in the study area reported a number of constraints. The major constraints mentioned by the farmers were lack of money, lack of scientific knowledge, poor fry quality, quality feeds, and high price of feed, off-odor, and low market price of pangus (Table 2). Rahman (2003) stated farming constraints are lack of money and higher production cost. Ali and Rahman (1986) stated that the none-availability of good quality fingerlings: both indigenous and exotic species was the major problem in Rangpur district. Hossain (2006) stated that the major problems were lack of proper knowledge, poor market price of fish, and lack of knowledge on water quality maintenance.

Table 2. Major problems in pangus farming in Trishal

\begin{tabular}{|c|c|c|c|c|c|}
\hline Problems & Lack of Money & $\begin{array}{c}\text { Lack of } \\
\text { Knowledge }\end{array}$ & $\begin{array}{c}\text { Poor quality of } \\
\text { Fry }\end{array}$ & $\begin{array}{c}\text { Low Market } \\
\text { Price }\end{array}$ & $\begin{array}{c}\text { High Price of } \\
\text { Feed }\end{array}$ \\
\hline$\%$ Farmer & 27 & 27 & 53 & 80 & 73 \\
\hline
\end{tabular}

\section{Socio-economic condition}

From the surveyed area it was founded that social statuses of the local people have been increased due to the commercial pangas culture practices. Results shows that $40 \%$ people reported that social status have been improved highly, $47 \%$ people reported that social statuses have been improved slightly and $13 \%$ farmer are unchanged (Fig. 15). Alam (2006) found that $70 \%$ of the fish growers could improve their socioeconomic condition through fish farming.

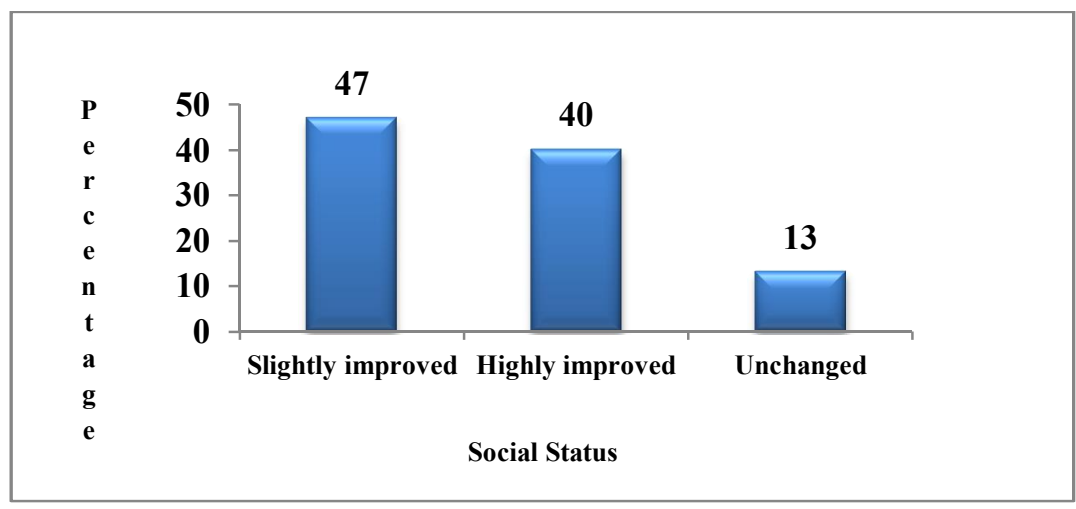

Fig. 15. Changes of socio-economic condition

\section{Conclusion}

Pangus culture started in Trishal Upazila mainly through awareness and training activities mostly conducted by the BFRI and DoF. Apart from some adverse socioeconomic condition and constraints of fish farming, farmers in this region contribute a remarkable part of inland fish production in Bangladesh. As the fishery sector plays a vital role in the socio-economic development, opportunity for employment, poverty alleviation and earning foreign currency for Bangladesh, it may be concluded that we have to reduce all the constraints of aquaculture to achieve sustainable production in future.

\section{References}

Ahmed F 2003: Comparative study on carp poly culture practices of three different NGOs in Mymensingh district, MS Thesis, Department of Fisheries Management, Bangladesh Agricultural University, Mymensingh. 
Akter N 2001: An economic analysis of pond pangus fish production in a selected area of Trishal Upazila in Mymensingh District. M.S. (Ag. Econ.) Thesis. Department of Agricultural Economics, Bangladesh Agricultural University, Mymensingh.

Ali, H. 2010. Cluster analysis of Pangasius aquaculture in Bangladesh based on geographical location and distribution. Unpublished field report. SEAT project, Bangladesh Agricultural University, Mymensingh and University of Stirling, UK.

Alam MF, Palash MS, Mian MIA and Dey MM. 2012. Marketing of Major Fish Species in Bangladesh: A Value Chain Analysis. Report submitted to Food and Agriculture Organization.

Alam G 2006: Status of fish farming and livelihoods of fish farmers in some selected areas of Mithapukur upazila in Rangpur district, MS Thesis, Department of Fisheries Management, Bangladesh Agricultural University, Mymensingh.

Ali MH, Rahman MI 1986: An investigation on some socio-economic and technical problems in pond fish culture in two districts of Bangladesh. Bangladesh J. Aquacult. 8(1) 47-5 1.

Bardach JE, Kyther JH Melarney WO 1972: Aquaculture: The farming and husbandry of Freshwater and Marine Organigm. Wileyinter Science,inc. NewYork. 868 pp.

Hassanuzzaman AKM 1997: Comparative study on pond fish production under different management systems in some selected areas of Rajshahi district, MS Thesis. Department of Agriculture Economics, BAU, Mymensingh.

Hossain MS, Alam M, Mazid MA 1992-94: Present status of pond fishery in four thanas under Chandpur district, Bangladesh. Bangladesh Journal of Aquaculture 12-14 1-6.

Hossain ME 2001: Effect of stocking density on the growth, survival and production of Thai Pangus (Pangasius hypophthalmus). M.S. Thesis, Department of Aquaculture, Bangladesh Agricultural University, Mymensingh.

Hossain A 2006: An economic analysis of pangas farming in rural Bangladesh. MS Thesis. Department of Fisheries Management, BAU, Mymensingh. 87pp.

Kausari, M.M.T. 2001. An economic study of pangas fish culture in selected area of Mymensingh and
Jamalpur district. MS Thesis. Department of Agricultural Economics, BAU, Mymensingh. $89 \mathrm{pp}$

Kundu D 2006: Present status of prawn farming and socio-economic condition of prawn farbnmers in some selected areas of Khulna district. MS Thesis. Department of Fisheries Management, BAU, Mymensingh. $107 \mathrm{pp}$.

Monir SM 2009: A study on technical aspects of Pangasius (Pangasianodon hypophthalamus) farming in Mymensingh region. MS Thesis, Department of Aquaculture, Bangladesh Agricultural University, Mymensingh.

New MB, Singholka S 1985: Fresh water prawn farming: A manual for the culture of Macrobrachium rosenbergii. FAO Fish. Tech. Pap. Rev. 225 $118 \mathrm{pp}$.

Parvin S 2011: Present status of commercial aquaculture in three upazila of Mymensingh district, MS Thesis, Department of Aquaculture, Bangladesh Agricultural University, Mymensingh.

Quddus MA, Moniruzzaman M 2000: Socio-economic conditions of the pond owners of Demra, Dhaka. Bangladesh J. Fish. 4(2): 203-207.

Rahman MM, 2003: Socio-economic aspects of carp culture development in Gazipur, Bangladesh, MS Thesis, Department of Fisheries Management, Bangladesh Agricultural University, Mymensingh.

Rahman MM 2006: Livelihoods of the people involved in pangasiid catfish (Pangasius hypophthalmus) farming in Mymensingh, MS Thesis, Department of Fisheries Management, BAU, Mymensingh.

Sadi AA 2013: Status of Pangas culture in three upazillas of Mymensingh region. MS Thesis. Department of Aquaculture, BAU, Mynensingh. 17pp.

Saha SR 2006: Status of pangasiid catfish (Pangasius hypophthalmus) farming in Mymensingh region, MS Thesis, Department of Fisheries Management, BAU, Mymensingh.

Wahab MA, Faruk MAR, Haque MM, Hossain MS 2008: $\quad$ Paper presented Pangasius (Pangasianodon hypophthalmus) farming in Bangladesh: current status and future challenges in the catfish symposium in Can Tho University, Can Tho Vietnam, 5-7 Dec, 2008. 